\title{
Rapid Reduction in Use of Antidiabetic Medication after Laparoscopic Sleeve Gastrectomy: The Newfoundland and Labrador Bariatric Surgery Cohort (BaSCo) Study
}

\author{
Carla Dillon, Justin Peddle, Laurie Twells, Kendra Lester, William Midodzi, Kimberley Manning, \\ Raleen Murphy, David Pace, Chris Smith, Darrell Boone, and Deborah Gregory
}

\begin{abstract}
Background: Patients who have undergone bariatric surgery generally need fewer medications as they experience improvement in, or even resolution of, various medical conditions, including type 2 diabetes mellitus, hypertension, and dyslipidemia. Published data on changes in medication use after laparoscopic sleeve gastrectomy, a type of bariatric surgery that is growing in popularity, are limited.

Objective: To determine whether patients took fewer medications for management of type 2 diabetes, hypertension, and dyslipidemia after laparoscopic sleeve gastrectomy, relative to preprocedure medications.

Methods: In this prospective, single-centre cohort study, a nurse practitioner used standard medication reconciliation and study dataextraction forms to interview adult patients who had undergone laparoscopic sleeve gastrectomy and determine their medication use and pertinent demographic data. The data were analyzed using generalized estimating equations and standard statistical software. Outcome measures included changes in the use of antidiabetic, antihypertensive, and antilipemic medications at 1,3 , and 6 months after the surgery.
\end{abstract}

Results: A total of 65 patients who underwent laparoscopic sleeve gastrectomy between May 2011 and January 2014 met the study inclusion criteria. Before surgery, the 30 patients with type 2 diabetes were taking an average of 1.9 antidiabetic medications. One month after the procedure, $15(50 \%)$ had discontinued all antidiabetic medications, with a further decline at 3 and 6 months ( $p<0.001$ at each time point). Among the patients who were taking antihypertensives $(n=48)$ and antilipemics $(n=33)$ before surgery, the decline in use occurred at a more modest rate, with $6(12 \%)$ and $2(6 \%)$, respectively, discontinuing these medication classes within 1 month, and $12(25 \%)(p=0.001)$ and $8(24 \%)(p=$ $0.015)$ having discontinued by 6 months.

Conclusions: These findings suggest that patients with a history of type 2 diabetes mellitus, hypertension, and/or dyslipidemia who undergo laparoscopic sleeve gastrectomy are less likely to require disease-specific medications shortly after surgery.

\section{RÉSUMÉ}

Contexte : Les patients ayant subi une chirurgie bariatrique ont généralement besoin de moins en moins de médicaments au fur et à mesure qu'ils voient leurs différentes affections, notamment le diabète sucré de type 2, l'hypertension et la dyslipidémie, s'estomper ou même se résorber. Or, il existe peu d'études publiées sur les changements apportés à la pharmacothérapie des patients ayant subi une gastrectomie longitudinale laparoscopique, une chirurgie bariatrique de plus en plus utilisée.

Objectif : Déterminer si les patients prennent moins de médicaments pour le traitement du diabète de type 2 , de l'hypertension et de la dyslipidémie après avoir subi une gastrectomie longitudinale laparoscopique comparativement à leur situation avant l'opération.

Méthodes : Dans cette étude de cohorte prospective menée dans un seul centre, un membre du personnel infirmier praticien a utilisé des formulaires standards de bilan comparatif des médicaments et d'extraction de données d'étude afin d'interroger des patients adultes ayant subi une gastrectomie longitudinale laparoscopique, et ce, dans le but de connaitre leur consommation de médicaments ainsi que de recueillir des données démographiques pertinentes. Les données ont été analysées à l'aide d'équations d'estimation généralisées et d'un logiciel statistique courant. Les critères de jugement incluaient l'adaptation du traitement antidiabétique, antihypertenseur et hypolipémiant, un mois, trois mois et six mois après la chirurgie.

Résultats : Au total, 65 patients ayant subi l'intervention chirurgicale entre mai 2011 et janvier 2014 ont été admis dans l'étude. Avant l'opération, les 30 patients atteints du diabète de type 2 prenaient en moyenne 1,9 antidiabétique. Un mois après la chirurgie, 15 (50\%) d'entre eux ont cessé de prendre des antidiabétiques, un chiffre qui a augmenté après le troisième et le sixième mois $(p<0,001$ à chaque point dans le temps). Parmi les patients qui prenaient des antihypertenseurs $(n=48)$ et des hypolipémiants $(n=33)$ avant l'intervention chirurgicale, un moins grand nombre a cessé de prendre ces médicaments. Seulement 6 (12\%) patients ont cessé les antihypertenseurs et 2 (6\%) patients ont cessé les 
Key Words: bariatric surgery, obesity, drug utilization, hypoglycemic agents, antihypertensive agents, hypolipidemic agents hypolipémiants après un mois, puis $12(25 \%)(p=0,001)$ et $8(24 \%)$ $(p=0,015)$ respectivement après six mois.

Conclusions : Ces résultats laissent croire que les patients atteints du diabète sucré de type 2, d'hypertension ou de dyslipidémie qui subissent une gastrectomie longitudinale laparoscopique courent la chance de ne plus avoir besoin de médicaments pour traiter ces maladies, et ce, peu de temps après la chirurgie.

Mots clés : chirurgie bariatrique, obésité, utilisation des médicaments, hypoglycémiants, antihypertenseurs, hypolipémiants

\section{INTRODUCTION}

$\mathrm{O}_{\mathrm{k}, \mathrm{s}}^{\mathrm{b}}$ besity is often categorized using body mass index (BMI, in $\mathrm{kg} / \mathrm{m}^{2}$ ) to reflect the health risk associated with increasing weight, especially with severe obesity (BMI $\geq 35) \cdot{ }^{1-4}$ Obese individuals are at increased risk of type 2 diabetes mellitus, hypertension, osteoarthritis, and some cancers (e.g., colorectal). ${ }^{2,5-7}$ Severe obesity is associated with a greater than 8-fold increased risk of diabetes relative to normal weight. ${ }^{8}$ Excessive body weight can significantly impair quality of life $\mathrm{f}^{9-15}$ and is associated with increased absenteeism from work, ${ }^{16,17}$ decreased work productivity, and decreased likelihood of employment. ${ }^{15,17-19}$ Severe obesity is also linked to increased use of health services and risk of premature death, with life expectancy being shortened by 5 to 13 years. $^{3-5,9,20-23}$

In 2011, about $10 \%$ of Canadian adults were classified as having severe obesity, and this proportion is projected to grow. ${ }^{24,25}$ Overall, it has been estimated that obesity (BMI $\geq 30)$ costs the Canadian economy $\$ 4.6$ billion annually, and many of these costs are associated with the management of obesity-associated chronic diseases. ${ }^{2,26}$ For adults with BMI of 35 or above and comorbid conditions refractory to medical treatment and for those with BMI of 40 or above, bariatric surgery is recommended. ${ }^{27,28}$ Bariatric surgery is the surgical manipulation of a portion of the gastrointestinal tract to limit food intake and/or caloric absorption. ${ }^{29}$ About 6000 bariatric procedures were performed in Canada in 2012-2013, an almost 4-fold increase over the preceding 6 years. ${ }^{30}$ Over the same period, there was also an increase in the number of Canadian hospitals performing bariatric surgery (from 34 to 46) ${ }^{30}$ Four types of bariatric procedures are available in Canada: Roux-en-Y gastric bypass, adjustable gastric banding, laparoscopic sleeve gastrectomy, and biliopancreatic diversion. ${ }^{30,31}$ Laparoscopic sleeve gastrectomy was originally a component of the biliopancreatic diversion with duodenal switch procedure and later was used as the first half of a staged procedure for patients with extremely high BMI.$^{32}$ It has now emerged as a stand-alone procedure, because of the substantial weight loss that has been observed following the surgery, and is gaining in popularity, ${ }^{30,33}$ representing $28 \%$ of bariatric surgeries performed in Canadian hospitals in 2012. ${ }^{30}$ This surgery involves removing most of the greater curvature of the stomach, leaving a gastric "tube" or sleeve with a capacity of 60 to 100 $\mathrm{mL} .{ }^{34}$ The procedure is well tolerated, has lower complication rates and a shorter operating time than Roux-en-Y gastric bypass, and achieves greater weight loss than adjustable gastric banding. ${ }^{35-37}$ Improvement in or resolution of diabetes, hypertension, and dyslipidemia has been observed after laparoscopic sleeve gastrectomy, although the mechanism is not clearly understood. ${ }^{38-40}$ Data specific to this procedure are limited, but published cost-effectiveness analyses of other bariatric procedures are favourable: \$12 701 per quality-adjusted life-year (QALY) over 10 years for diabetes, \$8659/QALY for hypertension, and $\$ 7811 /$ QALY for hyperlipidemia. ${ }^{40}$ One area of cost saving is the reduction in use of medications for chronic diseases. ${ }^{40,41}$ Information about medication use after laparoscopic sleeve gastrectomy is beginning to emerge but is currently limited to retrospective ${ }^{37,42}$ or small prospective studies (50 or fewer participants). ${ }^{43-45}$ However, the results are promising, showing a reduction in medication use, particularly for antidiabetic agents ${ }^{46,47}$ and for antihypertensive and lipid-lowering agents. ${ }^{37,43,44,48}$

This study was undertaken to determine whether patients were taking fewer medications for the management of diabetes, hypertension, and dyslipidemia at 1,3, and 6 months after laparoscopic sleeve gastrectomy.

\section{METHODS}

The provincial Health Research Ethics Authority granted approval to conduct the study. A cohort of patients 19 years of age and older who underwent laparoscopic sleeve gastrectomy at the Health Sciences Centre, Eastern Health site, of the provincial multidisciplinary bariatric surgery program located in St John's, Newfoundland and Labrador, were identified and followed prospectively.

A nurse practitioner (R.M.) screened patients for eligibility for the surgery. Patients selected for laparoscopic sleeve gastrectomy were those who met the eligibility criteria set out in the Canadian consensus guidelines for the treatment of obesity: adult patients with BMI of $35 \mathrm{~kg} / \mathrm{m}^{2}$ or greater and one or more specified comorbidities and those with BMI of $40 \mathrm{~kg} / \mathrm{m}^{2}$ or greater, regardless of comorbidities. ${ }^{27}$ All participants provided 
written, informed consent, which was obtained by the research nurse coordinator (K.M.).

The nurse practitioner used standard medication reconciliation and study data extraction forms to interview study participants. The analysis presented here covers only patients who had a diagnosis of diabetes, hypertension, and/or dyslipidemia and who were taking medications for at least one of these comorbid conditions at baseline. Type 2 diabetes mellitus was defined as fasting plasma glucose of $7.0 \mathrm{mmol} / \mathrm{L}$ or above or glycated hemoglobin (A1C) of $6.5 \%$ or above. ${ }^{49}$ Other patients whose diabetes was medically managed were identified through their medication-use profile, as well as self-reported medical history. Presence of diagnosed hypertension and dyslipidemia was based on self-reporting by patients. Data collected included demographic and clinical characteristics (e.g., age, sex, number and types of obesity-related comorbid conditions), pre- and postoperative anthropometric measurements (e.g., weight, height), and types and number of pre- and post-operative medications (both prescription and nonprescription).

The primary outcomes were the changes in use of antidiabetic, antihypertensive and antilipemic medications. Change was determined at 1, 3, and 6 months after surgery by 2 methods: (1) percentage of patients who were no longer taking any medications in the relevant class and (2) mean number of medications in the relevant class used by those who continued to require medications. The secondary outcome was weight loss, expressed in 2 ways: (1) excess weight loss $(\% \mathrm{EWL})=([\mathrm{W} 0-\mathrm{W} 1] /[\mathrm{W} 0-$ IBW]) $\times 100 \%$, where W0 is the preoperative weight $(\mathrm{kg})$, W1 is the weight at last follow-up (kg), and IBW is the ideal body weight $(\mathrm{kg})$ based on the Metropolitan Life tables for middle frame individuals ${ }^{50}$; and (2) percent change in total body weight $=([\mathrm{W} 0-\mathrm{W} 1] / \mathrm{W} 0) \times 100 \% .{ }^{51}$ Outcome measures were assessed at baseline (before surgery) and 1, 3, and 6 months after laparoscopic sleeve gastrectomy.

\section{Surgical Technique}

Each sleeve gastrectomy procedure was performed laparoscopically under general anesthesia. A 6-port technique was used, and a 42-Fr Bougie tube was used to determine the appropriate diameter of the sleeve. The sleeve was created using an endoscopic GIA stapler with Tri-Staple technology (Covidien Canada, Saint-Laurent, Quebec). The resection was started about $7 \mathrm{~cm}$ proximal from the pylorus. An endoscopic air leak test was routinely performed to confirm that the staple line was intact, and an upper gastrointestinal contrast study was performed on the first postoperative day, before introduction of an oral liquid diet.

\section{Statistical Analysis}

Statistical analyses were performed using SPSS Statistics for Windows, version 20.0 (IBM Corp, Armonk, New York). Data for continuous variables with a normal distribution are reported as mean \pm standard deviation (SD). Categorical variables are summarized as frequencies (i.e., numbers and percentages). Binary logistic regression models based on generalized estimating equations (GEEs) with exchangeable correlation were used to take into account the dependency between repeatedly measured outcomes. There were no missing data for patients' medications at any time point. The final multivariate GEE model produced adjusted odds ratios and 95\% confidence intervals (CIs). Statistical significance was set at $p<0.05 .{ }^{52}$

\section{RESULTS}

Between May 2011 and January 2014, a total of 188 laparoscopic sleeve gastrectomy procedures were performed. Within this cohort, 65 patients were taking an antidiabetic, antihypertensive, and/or antilipemic agent at baseline (see Table 1). Most of these patients were women (50/65 [77\%]), and most were

\section{Table 1. Baseline Characteristics of Patients before Laparoscopic Sleeve Gastrectromy*}

\begin{tabular}{|c|c|}
\hline Characteristic & $\begin{array}{l}\text { Mean } \pm \text { SD or } \\
\text { No. }(\%) \text { of Patients }\end{array}$ \\
\hline Age, years $(n=65)$ & $47.4 \pm 10.6$ \\
\hline Sex, female & $50 / 65(77)$ \\
\hline Ethnicity, white & $58 / 64(91)$ \\
\hline Education, completed postsecondary & $41 / 64(64)$ \\
\hline Marital status, married or common-law & $51 / 64(80)$ \\
\hline Weight, $\mathrm{kg}(n=65)$ & $133.9 \pm 23.1$ \\
\hline Waist circumference, $\mathrm{cm}(n=48)$ & $140.5 \pm 15.7$ \\
\hline BMI, $\mathrm{kg} / \mathrm{m}^{2}(n=65)$ & $48.9 \pm 6.9$ \\
\hline Obesity class II & 6/65 (9) \\
\hline Obesity class III & $59 / 65(91)$ \\
\hline \multicolumn{2}{|l|}{ Chronic conditions } \\
\hline Mean no. per patient $(n=64)$ & $6.6 \pm 3.0$ \\
\hline With 0 comorbidities & 0/64 (0) \\
\hline With 1 comorbidity & $1 / 64(2)$ \\
\hline With 2 comorbidities & $0 / 64(0)$ \\
\hline With 3 comorbidities & $8 / 64(12)$ \\
\hline With $\geq 4$ comorbidities & $55 / 64(86)$ \\
\hline Type 2 diabetes mellitus & $40 / 65(62)$ \\
\hline Hypertension & $48 / 64(75)$ \\
\hline Dyslipidemia & $43 / 63(68)$ \\
\hline $\mathrm{A} 1 \mathrm{C}, \%(n=65)$ & $7.0 \pm 1.5$ \\
\hline Fasting glucose, $\mathrm{mmol} / \mathrm{L}(n=65)$ & $7.2 \pm 2.6$ \\
\hline \multicolumn{2}{|l|}{ Blood pressure, $\mathrm{mm} \mathrm{Hg}(n=65)$} \\
\hline Systolic & $132 \pm 14.0$ \\
\hline Diastolic & $81 \pm 10.7$ \\
\hline \multicolumn{2}{|l|}{ Cholesterol, mmol/L } \\
\hline Total $(n=64)$ & $4.6 \pm 1.1$ \\
\hline $\operatorname{LDL}(n=63)$ & $2.7 \pm 1.0$ \\
\hline $\mathrm{HDL}(n=64)$ & $1.0 \pm 0.2$ \\
\hline Triglycerides, $\mathrm{mmol} / \mathrm{L}(n=64)$ & $2.0 \pm 0.8$ \\
\hline Cholesterol ratio (total:HDL) $(n=64)$ & $4.7 \pm 1.3$ \\
\hline \multicolumn{2}{|c|}{$\begin{array}{l}\mathrm{A} 1 \mathrm{C}=\text { glycated hemoglobin, } \mathrm{BMI}=\text { body mass index, } \\
\mathrm{HDL}=\text { high-density lipoprotein, } \mathrm{LDL}=\text { low-density lipoprotein, } \\
\mathrm{SD}=\text { standard deviation. } \\
\text { *The study sample consisted of } 65 \text { patients, but for some } \\
\text { variables, data were missing for some patients. The sample } \\
\text { size is shown for each variable. }\end{array}$} \\
\hline
\end{tabular}


white (58/64 [91\%]), with an average age of 47.4 years. The average preoperative weight was $133.9 \mathrm{~kg}$, and BMI was 48.9 (obesity class III).

Of the 188 patients who underwent laparoscopic sleeve gastrectomy during the study period, 63 (34\%) had diabetes, and almost half of these $(n=30)$ were taking antidiabetic medications at baseline and had follow-up data at 1, 3, and 6 months. Of the 88 patients who self-reported hypertension, just over half $(n=48)$ were taking antihypertensives and had follow-up data at 1,3 , and 6 months; similarly, of the 84 patients with self-reported dyslipidemia, close to $40 \%(n=33)$ were taking antilipemics at baseline and had follow-up data at 1, 3, and 6 months.

Metformin was the most common antidiabetic medication, taken by $80 \%$ (24/30) of those who were receiving antidiabetic medications. Of those with hypertension who were taking an antihypertensive agent, the majority (38/48 [79\%]) were taking a diuretic, of which hydrochlorothiazide was the most commonly used. 3-Hydroxy-3-methyl-glutaryl (HMG) CoA reductase inhibitors (statins) were being taken by $94 \%$ (31/33) of patients with dyslipidemia who were taking an antilipemic agent.

A dramatic reduction in the use of antidiabetic agents was seen as early as 1 month after the surgery (Figure 1 ). At 1 month, half of the patients (15/30) had discontinued antidiabetic medication $(p<0.001)$. This reduction in use was still present at 3 and 6 months, with $47 \%(14 / 30)$ taking antidiabetic agents at each of these time points $(p<0.001)$. The use of antihypertensive agents also declined, although to a more modest extent. More specifically, a reduction of $12 \%$ (i.e., 6 patients no longer were taking antihypertensives) was seen at 1 month $(p=0.008)$. This decreased use continued at each of the subsequent time points, with $81 \%(39 / 48 ; p=0.003)$ and $75 \%(36 / 48 ; p=0.001)$ of patients still taking antihypertensive agents at 3 and 6 months, respectively. A similar, gradual decrease was seen in the use of antilipemic agents, with $94 \%(31 / 33)$ continuing to use these agents at 1 month, $85 \%(28 / 33)$ at 3 months, and $76 \%(25 / 33)$ at 6 months ( $p=0.015$ at 6 months).

At baseline, the patients with diabetes who were being treated with medications were taking an average of 1.9 antidiabetic medications (Figure 2). This number decreased to 0.9 at 1 month, 0.8 at 3 months, and 0.6 at 6 months $(p<0.001$ for each time point relative to baseline) (Figure 2). At baseline, the patients who were taking antihypertensive agents were taking an average of 2.2 drugs from this class of medications. The mean number declined to 1.7 at 1 month, 1.5 at 3 months, and 1.3 at 6 months ( $p \leq 0.001$ for each time point relative to baseline). Patients in the study sample who had dyslipidemia either were not taking an antilipemic agent or were taking only one antilipemic agent at any time point, so average numbers of antilipemic medications were not calculated.

At baseline, patients were taking between 1 and 4 antidiabetic medications (Figure 3). The number of medications shifted dramatically as early as 1 month after the surgery, and by 6 months, most of the patients were taking no antidiabetic medications $(16 / 30$ [53\%]) or a single medication (10/30 [33\%]), with the maximum number of antidiabetic agents being 2 (for $4 / 30$ patients [13\%]). These changes were statistically significant at all time points $(p<0.01)$. The overall odds ratio for use of antidiabetic medications before versus after laparoscopic sleeve gastrectomy was 0.22 (95\% CI 0.12-0.40). A similar shift was seen for antihypertensive agents, although less dramatic (data not shown). The reductions in use of antihypertensive agents were statistically significant at 3 and 6 months $(p<0.05)$ : more specifically, the majority of patients were taking 1 antihypertensive (12/48 [25\%]) or 2 antihypertensives (21/48 [44\%]) at baseline, whereas the majority were taking no antihypertensives (12/48 [25\%]) or 1 antihypertensive (17/48 [35\%]) by 6 months. The

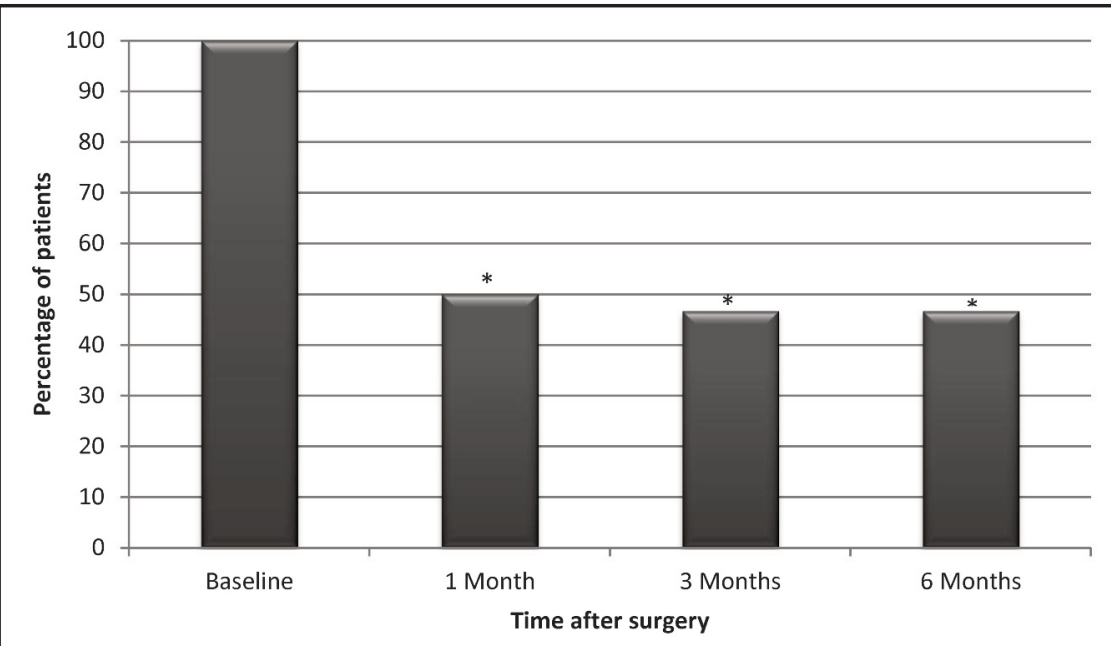

Figure 1. Proportions of patients continuing antidiabetic medications after laparoscopic sleeve gastrectomy $(n=30)$. ${ }^{\star} p<0.001$ for comparison with baseline. 


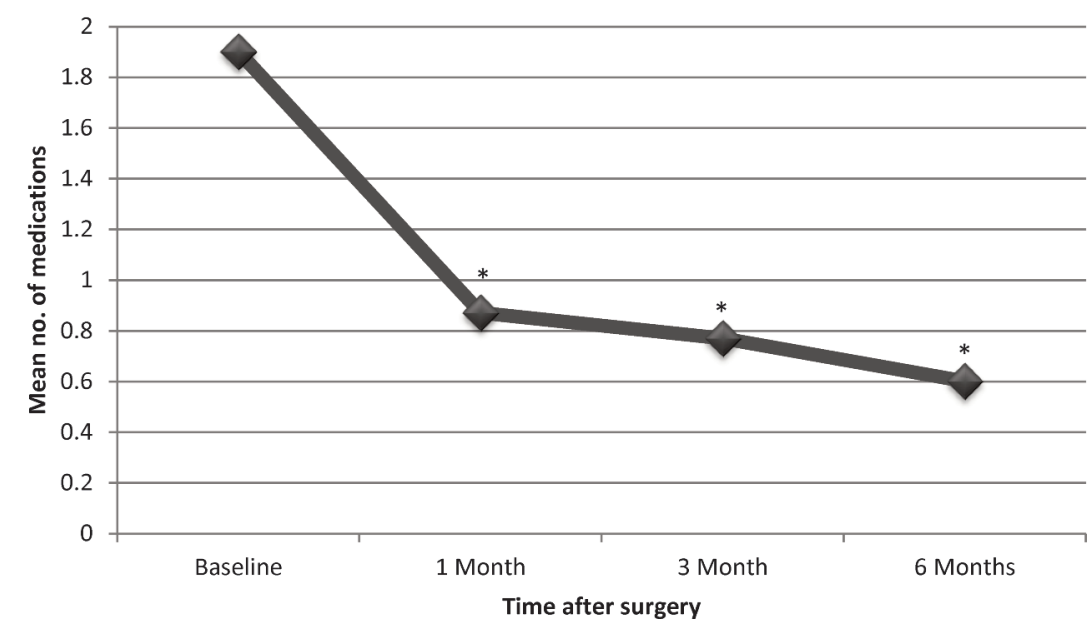

Figure 2. Average number of antidiabetic medications ( $n=30$ patients). ${ }^{*} p<0.001$ for comparison with baseline.

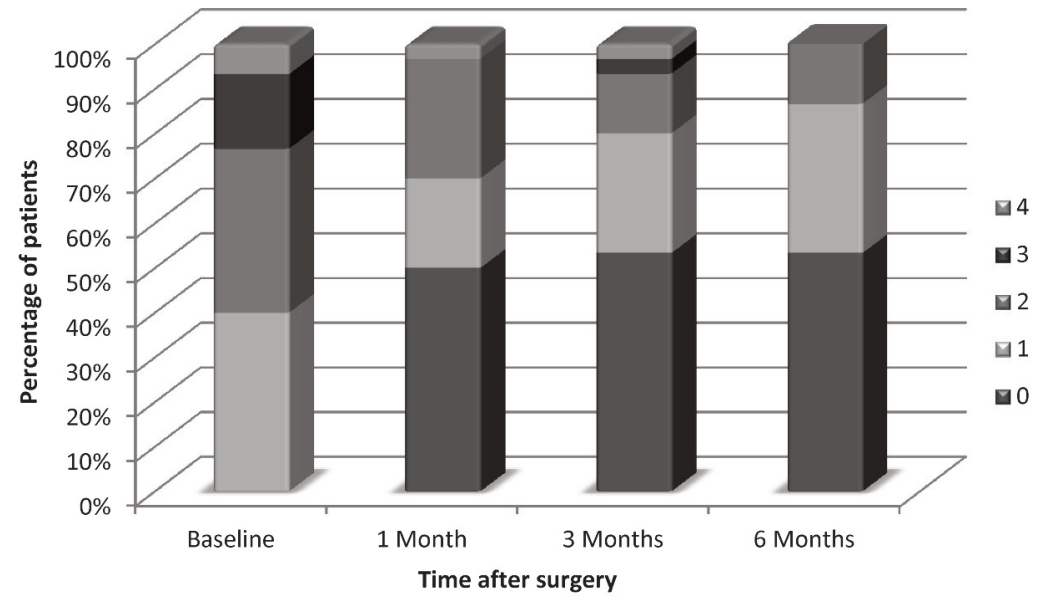

Figure 3. Number of antidiabetic medications ( $n=30$ patients).

overall odds ratios for use of medications before versus after laparoscopic sleeve gastrectomy were 0.20 (95\% CI 0.07-0.54) for antihypertensives and 0.71 (95\% CI 0.55-0.91) for antilipemics ( $p<0.01$ for both).

Changes in selected weight loss measures for patients who were taking antidiabetic agents at baseline (Table 2) were significant relative to baseline $(p<0.001)$ and are also considered clinically important.

\section{DISCUSSION}

In this prospective cohort study of patients undergoing laparoscopic sleeve gastrectomy, there was a dramatic and early reduction in the use of antidiabetic medications, with half of the patients who were taking such medications at the time of surgery discontinuing medical therapy by 1 month after the procedure and a further reduction in use at 3 and 6 months. The use of antihypertensive and antilipemic medications also decreased by 1 month after laparoscopic sleeve gastrectomy, with further reductions at 3 and 6 months, although these declines were not as dramatic.

These findings suggest that the benefit of bariatric surgery goes beyond a reduction in weight, with improvements in chronic conditions such as diabetes starting before significant weight loss occurs. It is possible that these changes are related to dietary changes after the procedure. The day after surgery, the dietitian advises patients about the strict diet that must be followed immediately after surgery, starting with an all-fluid diet for the first 4 weeks. The dietitian also instructs patients as to what foods they will be allowed to eat as they progress from a full-fluid diet to solid foods. Patients meet again with the dietitian 
This single copy is for your personal, non-commercial use only.

For permission to reprint multiple copies or to order presentation-ready copies for distribution, contact CJHP at cjhpedit@cshp.ca

\section{Table 2. Weight Loss Measures for Patients Taking Antidiabetic Medications before Laparoscopic Sleeve Gastrectromy $(n=30)$}

Time after Laparoscopic Sleeve Gastrectromy; Mean (SD) for Measure*

\begin{tabular}{|c|c|c|c|}
\hline Measure & 1 Month & 3 Months & 6 Months \\
\hline \multicolumn{4}{|l|}{ Absolute change in body weight } \\
\hline As \% of initial body weight & $-8.0(2.5)$ & $-14.8(2.7)$ & $-20.9(3.6)$ \\
\hline In $\mathrm{kg}$ & $-11.1(4.7)$ & $-20.5(6.0)$ & $-28.8(8.1)$ \\
\hline Absolute change in $\mathrm{BMI}, \mathrm{kg} / \mathrm{m}^{2}$ & $-3.9(1.5)$ & $-7.3(1.8)$ & $-10.3(2.5)$ \\
\hline$\%$ of excess weight lost & $-15.1(4.8)$ & $-28.1(6.1)$ & $-39.6(7.4)$ \\
\hline
\end{tabular}

$\mathrm{BMI}=$ body mass index, SD = standard deviation.

*For all values reported in this table, $p<0.001$ compared with baseline.

at 4 weeks after surgery and with the surgeon 6 to 8 weeks postoperatively. An alternative explanation for the observed changes in medication use is the "foregut theory" or "gastric hypothesis", which postulates that a reduction in ghrelin levels contributes to early weight loss. Ghrelin is a gastric hormone that stimulates appetite, and removal of the fundus by laparoscopic sleeve gastrectomy removes the primary site of ghrelin production. ${ }^{39}$

Padwal and others ${ }^{53}$ described the characteristics of the population of patients who undergo publicly funded bariatric surgery in Canada. The subsample in the current study showed similarities to the Canadian population undergoing bariatric surgery with respect to average age, ethnicity, proportion of women, and level of education. For example, in Canada, the average age of surgical patients is $43.6 \pm 11.1$ years, $87 \%$ are white, and $82 \%$ of the population is female. In the current study, the average age was $47.4 \pm 10.6$ years, $91 \%$ of the sample was white, and $77 \%$ were female. Padwal and others ${ }^{53}$ described patients undergoing surgery as highly educated, with $56.9 \%$ of the eligible population having received some postsecondary education; educational achievement in the current study sample was similar, with $64 \%$ of the sample having received a college diploma or university degree. However, the prevalence of obesity-related comorbidities was much higher in the Newfoundland and Labrador sample than in the Canadian population undergoing bariatric surgery: $35 \%$ versus $21.1 \%$ for diabetes, $48 \%$ versus $13.1 \%$ for hypertension, and $47 \%$ versus $2.4 \%$ for dyslipidemia.

Like this study, other research has shown a dramatic reduction in the use of antidiabetic agents within 1 month after laparoscopic sleeve gastrectomy, which was maintained or further reduced over longer periods. ${ }^{43,45,48,54,55}$ Also similar to the current study, the use of antihypertensive and antilipemic agents declined in other studies, but to a lesser extent than for antidiabetic agents. ${ }^{43,48}$ In contrast, in the study by Ruiz-Tovar and others, ${ }^{56}$ in which a 50-Fr Bougie tube was used, a dramatic reduction in the use of antihypertensive agents was reported, with all 9 patients discontinuing this class of medication by 6 months after the surgery.

Similar reductions in medication use have been observed after Roux-en-Y gastric bypass. For example, Snow and others ${ }^{57}$ observed a mean reduction of 2.7 drugs per patient, with a corresponding $72 \%$ mean reduction in drug cost, 2 years after Roux-en-Y gastric bypass. Malone and Alger-Mayer ${ }^{58}$ investigated specific drug class changes 1 year after Roux-en-Y gastric bypass and found significant reductions in the use of antidiabetic (insulin, sulfonylureas, and metformin), antihypertensive (calcium-channel blockers, angiotensin-converting enzyme inhibitors or receptor blockers, and diuretics), and lipid-lowering medications. In a retrospective study of over 2000 patients with diabetes, $85 \%$ of patients were no longer taking antidiabetic medications 2 years after surgery, the majority of the procedures being Roux-en-Y gastric bypass. ${ }^{59}$

With the significant and rapid reduction in need for antidiabetic and antihypertensive agents after bariatric procedures, pharmacists have an important role to play. Before the surgery, pharmacists should interview patients to compile an accurate list of current medications. After the surgery, pharmacists should consider whether antidiabetic and antihypertensive agents should be restarted, and if so should recommend dose reductions with close monitoring. For patients continuing use of antidiabetic and antihypertensive agents after discharge, pharmacists should provide education about the importance of monitoring for signs and symptoms of hypoglycemia and hypotension, and should recommend further dose reductions or discontinuation of medications as appropriate. ${ }^{60}$

Interventions to reduce obesity are important to combat this epidemic in developed countries, especially in the location of this study, Newfoundland and Labrador, where $27.7 \%$ of residents are classified as obese, with a projected increase to $34.6 \%$ by $2019 .^{24,61}$ Sleeve gastrectomy offers an effective alternative to Roux-en-Y gastric bypass. ${ }^{62}$

A number of limitations should be considered when these findings are interpreted. First, the study was observational, and as such there is potential for unmeasured confounders to have influenced the results. For example, patients' adherence to prescribed medication therapy was unknown. In addition, the duration of diabetes has been shown to be a predictor of diabetes outcome after laparoscopic sleeve gastrectomy. ${ }^{63}$ The authors are in the process of extracting this information for patients included in the current study and will be able to consider this factor in 
This single copy is for your personal, non-commercial use only.

For permission to reprint multiple copies or to order presentation-ready copies for distribution, contact CJHP at cjhpedit@cshp.ca

future analysis of a larger cohort. Second, longer-term follow-up is needed to assess continued partial or prolonged remission of comorbidities. Third, differences in surgical techniques may be a factor leading to between-study differences in rates.

\section{CONCLUSION}

Improvement of obesity-related comorbidities was observed in patients who underwent laparoscopic sleeve gastrectomy. Specifically, the use of antidiabetic, antihypertensive, and antilipemic medications decreased early (i.e., 1 month) after the surgery, ahead of significant weight loss, and the decrease in medication use was sustained over a 6-month period. These changes in medication therapy translate into significant cost savings. As such, the current findings have implications for health care policy.

\section{References}

1. Body mass index (BMI) nomogram. In: Canadian guidelines for body weight classification in adults. Ottawa (ON): Health Canada; 2003 [modified 2012 Feb 23; cited 2014 Jun 21]. Available from: www.hcsc.gc.ca/fn-an/nutrition/weights-poids/guide-ld-adult/bmi_chart_javagraph_imc_java-eng.php

2. Obesity in Canada: a joint report from the Public Health Agency of Canada and the Canadian Institute for Health Information. Ottawa (ON): Public Health Agency of Canada and Canadian Institute for Health Information; 2011 [cited 2014 Jun 21]. Available from: https://secure.cihi.ca/free_ products/Obesity_in_canada_2011_en.pdf

3. Prospective Studies Collaboration, Whitlock G, Lewington S, Sherliker P, Clarke R, Emberson J, Halsey J, et al. Body-mass index and cause-specific mortality in 900000 adults: collaborative analyses of 57 prospective studies. Lancet. 2009;373(9669):1083-96.

4. Fontaine KR, Redden DT, Wang C, Westfall AO, Allison DB. Years of life lost due to obesity. JAMA. 2003;289(2):187-93.

5. Guh DP, Zhang W, Bansback N, Amarsi Z, Birmingham CL, Anis AH. The incidence of co-morbidities related to obesity and overweight: a systematic review and meta-analysis. BMC Public Health. 2009;9:88.

6. Luo W, Morrison H, de Groh M, Waters C, DesMeules M, Jones-McLean E, et al. The burden of adult obesity in Canada. Chronic Dis Can. 2007; 27(4):135-44.

7. Bray GA. Medical consequences of obesity. J Clin Endocrinol Metab. 2004; 89(6):25839

8. Must A, Spadano J, Coakley EH, Field AE, Colditz G, Dietz WH. The disease burden associated with overweight and obesity. JAMA. 1999; 282(16):1523-9.

9. Tarride JE, Haq M, Taylor VH, Sharma AM, Nakhai-Pour HR, O'Reilly $\mathrm{D}$, et al. Health status, hospitalizations, day procedures, and physician costs associated with body mass index (BMI) levels in Ontario, Canada. Clinicoecon Outcomes Res. 2012;4:21-30.

10. de Hollander EL, Picavet HS, Milder IE, Verschuren WM, Bemelmans WJ, de Groot LC. The impact of long-term body mass index patterns on healthrelated quality of life: the Doetinchem Cohort Study. Am J Epidemiol. 2013;178(5):804-12.

11. Keating CL, Peeters A, Swinburn BA, Magliano DJ, Moodie ML. Utilitybased quality of life associated with overweight and obesity: the Australian diabetes, obesity, and lifestyle study. Obesity (Silver Spring). 2013;21(3):652-5.

12. Taylor VH, Forhan M, Vigod SN, McIntyre RS, Morrison KM. The impact of obesity on quality of life. Best Pract Res Clin Endocrinol Metab. 2013; 27(2):139-46.

13. Jia H, Lubetkin EI. The impact of obesity on health-related quality-oflife in the general adult US population. J Public Health $(O x f) .2005$; 27(2):156-64

14. McLaren L. Socioeconomic status and obesity. Epidemiol Rev. 2007;29:29-48.

15. Puhl RM, Heuer CA. The stigma of obesity: a review and update. Obesity (Silver Spring). 2009;17(5):941-64.

16. Howard JT, Potter LB. An assessment of the relationships between overweight, obesity, related chronic health conditions and worker absenteeism. Obes Res Clin Pract. 2014;8(1):e1-15.
17. Klarenbach S, Padwal R, Chuck A, Jacobs P. Population-based analysis of obesity and workforce participation. Obesity (Silver Spring). 2006; 14(5):920-7.

18. Neovius K, Johansson K, Rössner S, Neovius M. Disability pension, employment and obesity status: a systematic review. Obes Rev. 2008; 9(6):572-81.

19. van Duijvenbode DC, Hoozemans MJM, van Poppel MN, Proper KI. The relationship between overweight and obesity, and sick leave: a systematic review. Int J Obes (Lond). 2009;33(8):807-16.

20. Peeters A, Barendregt JJ, Willekens F, Mackenbach JP, Al Mamun A, Bonneux L; NEDCOM, Netherlands Epidemiology and Demography Compression of Morbidity Research Group. Obesity in adulthood and its consequences for life expectancy: a life-table analysis. Ann Intern Med. 2003;138(1):24-32.

21. Allison DB, Fontaine KR, Manson JE, Stevens J, Vanltallie TB. Annual deaths attributable to obesity in the United States. JAMA. 1999; 282(16):1530-8.

22. Twells LK, Bridger T, Knight JC, Alaghehbandan R, Barrett B. Obesity predicts primary health care visits: a cohort study. Popul Health Manag. 2012;15(1):29-36.

23. Katzmarzyk PT, Ardern CI. Overweight and obesity mortality trends in Canada, 1985-2000. Can J Public Health. 2004;95(1):16-20.

24. Twells LK, Gregory DM, Reddigan J, Midodzi WK. Current and predicted prevalence of obesity in Canada: a trend analysis. CMAJ Open. 2012 [cited 2014 Sep 22];2(1):E18-26. Available from: http://cmajopen.ca/content/ 2/1/E18.full

25. Canadian Health Measures Survey: cycle 2 data tables, 2009 to 2011. Ottawa (ON): Statistics Canada, Health Statistics Division; 2013 [modified 2013 Apr 17; cited 2014 Nov 30]. Available from: www.statcan.gc.ca/ pub/82-626-x/82-626-x2013001-eng.htm

26. Moffatt E, Shack LG, Petz GJ, Sauvé JK, Hayward K, Colman R. The cost of obesity and overweight in 2005: a case study of Alberta, Canada. Can J Public Health. 2011;102(2):144-8.

27. Lau DC; Obesity Canada Clinical Practice Guidelines Steering Committee and Expert Panel. Synopsis of the 2006 Canadian clinical practice guidelines on the management and prevention of obesity in adults and children. CMAJ. 2007;176(8):1103-6.

28. Wharton S, Sharma AM, Lau DC. Canadian Diabetes Association 2013 clinical practice guidelines for the prevention and management of diabetes in Canada: weight management in diabetes. Can J Diabetes. 2013;37 Suppl 1:S82-6. Available from: http://guidelines.diabetes.ca/fullguidelines/ Chapter17

29. Schirmer B, Schauer PR. Chapter 27. The surgical management of obesity. In: Brunicardi F, Andersen DK, Billiar TR, Dunn DL, Hunter JG, Matthews JB, et al., editors. Schwartz's principles of surgery. 9th ed. New York (NY): McGraw-Hill; 2010 [cited 2015 Mar 26]. Available from: http:// accessmedicine. $\mathrm{mhmedical}$.com/content.aspx?bookid=352\&Sectionid= 40039769

30. Bariatric surgery in Canada. Ottawa $(\mathrm{ON})$ : Canadian Institute for Health Information; 2014 May [cited 2014 Jun 21]. Available from: https:// secure.cihi.ca/free_products/Bariatric_Surgery_in_Canada_EN.pdf

31. Arkinson J, Ji H, Fallah S, Pérez J, Chen XK, Leeb K. Bariatric surgery in Canada: a focus on day surgery procedures. Healthc Q. 2010;13(3):15-8.

32. Regan JP, Inabnet WB, Gagner M, Pomp A. Early experience with twostage laparoscopic Roux-en-Y gastric bypass as an alternative in the supersuper obese patient. Obes Surg. 2003;13(6):861-4.

33. Buchwald H, Oien DM. Metabolic/bariatric surgery worldwide 2011. Obes Surg. 2013;23(4):427-36.

34. Padwal R, Klarenbach S, Wiebe N, Hazel M, Birch D, Karmali S, et al. Bariatric surgery: a systematic review of the clinical and economic evidence. J Gen Intern Med. 2011;26(10):1183-94.

35. Trastulli S, Desiderio J, Guarino S, Cirocchi R, Scalercio V, Noya G, et al. Laparoscopic sleeve gastrectomy compared with other bariatric surgical procedures: a systematic review of randomized trials. Surg Obes Relat Dis. 2013;9(5):816-29.

36. Himpens J, Dapri G, Cadière GB. A prospective randomized study between laparoscopic gastric banding and laparoscopic isolated sleeve gastrectomy: results after 1 and 3 years. Obes Surg. 2006;16(11):1450-6.

37. Carlin AM, Zeni TM, English WJ, Hawasli AA, Genaw JA, Krause KR, et al; Michigan Bariatric Surgery Collaborative. The comparative effectiveness of sleeve gastrectomy, gastric bypass, and adjustable gastric banding procedures for the treatment of morbid obesity. Ann Surg. 2013;257(5):791-7.

38. Via MA, Mechanick JI. The role of bariatric surgery in the treatment of type 2 diabetes: current evidence and clinical guidelines. Curr Atheroscler Rep. 2013;15(11):366 
39. Anderson B, Switzer NJ, Almamar A, Shi X, Birch DW, Karmali S. The impact of laparoscopic sleeve gastrectomy on plasma ghrelin levels: a systematic review. Obes Surg. 2013;23(9):1476-80.

40. Bariatric surgery for obese patients with co-morbidities: a review of clinical effectiveness, cost-effectiveness, and guidelines. Ottawa $(\mathrm{ON})$ : Canadian Agency for Drugs and Technologies in Health; 2013 Aug 8 [cited 2014 Jun 21]. Available from: www.cadth.ca/media/pdf/htis/aug-2013/RC0468\% 20Bariatric\%20Surgery\%20Final.pdf

41. Neovius M, Narbro K, Keating C, Peltonen M, Sjöholm K, Agren G, et al. Health care use during 20 years following bariatric surgery. JAMA. 2012;308(11):1132-41

42. Jacobs M, Bisland W, Gomez E, Plasencia G, Mederos R, Celaya C, et al. Laparoscopic sleeve gastrectomy: a retrospective review of 1- and 2-year results. Surg Endosc. 2010;24(4):781-5.

43. Leonetti F, Capoccia D, Coccia F, Casella G, Baglio G, Paradiso F, et al. Obesity, type 2 diabetes mellitus, and other comorbidities: a prospective cohort study of laparoscopic sleeve gastrectomy vs medical treatment. Arch Surg. 2012;147(8):694-700.

44. Saul D, Stephens D, Hofstätter Rde C, Ahmed L, Langhoff E, Heimann TM. Preliminary outcomes of laparoscopic sleeve gastrectomy in a Veterans Affairs medical center. Am J Surg. 2012;204(5):e1-6.

45. Slater BJ, Bellatorre N, Eisenberg D. Early postoperative outcomes and medication cost savings after laparoscopic sleeve gastrectomy in morbidly obese patients with type 2 diabetes. J Obes. 2011;2011:350523.

46. Gill RS, Birch DW, Shi X, Sharma AM, Karmali S. Sleeve gastrectomy and type 2 diabetes mellitus: a systematic review. Surg Obes Relat Dis. 2010; 6(6):707-13.

47. Yip S, Plank LD, Murphy R. Gastric bypass and sleeve gastrectomy for type 2 diabetes: a systematic review and meta-analysis of outcomes. Obes Surg. 2013;23(12):1994-2003.

48. Schauer PR, Kashyap SR, Wolski K, Brethauer SA, Kirwan JP, Pothier CE, et al. Bariatric surgery versus intensive medical therapy in obese patients with diabetes. N Engl J Med. 2012:26;366(17):1567-76.

49. Goldenberg R, Punthakee Z. Canadian Diabetes Association 2013 clinical practice guidelines for the prevention and management of diabetes in Canada: definition, classification and diagnosis of diabetes, prediabetes and metabolic syndrome. Can J Diabetes. 2013;37 Suppl 1:S8-11. Available from: http://guidelines.diabetes.ca/Browse/Chapter3

50. 1983 Metropolitan height and weight tables. Stat Bull Metrop Life Found. 1983;64(1):3-9

51. Powers KA, Rehriq ST, Jones DB. Financial impact of obesity and bariatric surgery. Med Clin North Am. 2007;91(3):321-38.

52. Twisk JWR. Applied longitudinal data analysis for epidemiology: a practical guide. New York (NY): Cambridge University Press; 2003.

53. Padwal RS, Chang HJ, Klarenbach S, Sharma AM., Majunmdar SR. Characteristics of the population eligible for and receiving publicly funded bariatric surgery in Canada. Int J Equity Health. 2012;11:54.

54. Shah PS, Todkar JS, Shah SS. Effectiveness of laparoscopic sleeve gastrectomy on glycemic control in obese Indians with type 2 diabetes mellitus. Surg Obes Relat Dis. 2010;6(2):138-41.

55. Casella G, Abbatini F, Calì B, Capoccia D, Leonetti F, Basso N. Ten-year duration of type 2 diabetes as prognostic factor for remission after sleeve gastrectomy. Surg Obes Relat Dis. 2011;7(6):697-702.

56. Ruiz-Tovar J, Oller I, Tomas A, Llavero C, Arrovo A, Calero A, et al. Midterm impact of gleeve gastrectomy, calibrated with a 50-Fr bougie, on weight loss, glucose homeostatsis, lipid profiles, and comorbidities in morbidly obese patients. Am Surg. 2012;78(9):969-74.

57. Snow LL, Weinstein LS, Hannon JK, Lane DR, Ringold FG, Hansen PA, et al. The effect of Roux-en-Y gastric bypass on prescription drug costs. Obes Surg. 2004;14(8):1031-5.

58. Malone M, Alger-Mayer SA. Medication use patterns after gastric bypass surgery for weight management. Ann Pharmacother. 2005;39(4):637-42.

59. Makary MA, Clark JM, Shore AD, Magnuson TH, Richards T, Bass EB, et al. Medication utilization and annual health care costs in patients with type 2 diabetes mellitus before and after bariatric surgery. Arch Surg. 2010; 145(8):726-31.

60. Quidley AM, Bland CM, Bookstaver PB, Kuper K. Perioperative management of bariatric surgery patients. Am J Health Syst Pharm. 2014; 71:1253-64.

61. World Health Organization. Obesity: preventing and managing the global epidemic. Report of a WHO consultation. World Health Organ Tech Rep Ser. 2000 [cited 2014 Sep 22];894:i-xii, 1-253. Available from: www.who. int/nutrition/publications/obesity/WHO_TRS 894/en/
62. de Gordejuela AG, Pujol Gebelli J, García NV, Alsina EF, Medayo LS, Masdevall Noguera C. Is sleeve gastrectomy as effective as gastric bypass for remission of type 2 diabetes in morbidly obese patients? Surg Obes Relat Dis. 2011;7(4):506-9.

63. Vidal J, Ibarzabal A, Romero F, Delgado S, Momblán D, Flores L, et al. Type 2 diabetes mellitus and the metabolic syndrome following sleeve gastrectomy in severely obese subjects. Obes Surg. 2008;18(9):1077-82.

Carla Dillon, BScPharm, ACPR, PharmD, is with the School of Pharmacy and Faculty of Medicine, Memorial University of Newfoundland, St John's, Newfoundland and Labrador

Justin Peddle, BScPharm, PharmD, is with the School of Pharmacy, Memorial University of Newfoundland, St John's, Newfoundland and Labrador.

Laurie Twells, BA, MSc, PhD, is with the School of Pharmacy and Faculty of Medicine, Memorial University of Newfoundland, St John's, Newfoundland and Labrador.

Kendra Lester, BSc, MSc, is with the Faculty of Medicine, Memorial University of Newfoundland, St John's, Newfoundland and Labrador.

William Midodzi, PhD, is with the Faculty of Medicine, Memorial University of Newfoundland, St John's, Newfoundland and Labrador.

Kimberley Manning, RN, is with Eastern Health, St John's, Newfoundland and Labrador.

Raleen Murphy, NP, MSc(A), BSc, is with Eastern Health, St John's, Newfoundland and Labrador.

David Pace, BSC, MBA, MD, FRCSC, is with Eastern Health and the Faculty of Medicine, Memorial University of Newfoundland, St John's, Newfoundland and Labrador.

Chris Smith, BSC(Hons), MD, FRCSC, is with Eastern Health and the Faculty of Medicine, Memorial University of Newfoundland, St John's, Newfoundland and Labrador.

Darrell Boone, BMedSC, MD, FRCSC, is with Eastern Health and the Faculty of Medicine, Memorial University of Newfoundland, St John's, Newfoundland and Labrador

Deborah Gregory, BN, MSc, PhD, is with the Faculty of Medicine, Memorial University of Newfoundland, St John's, Newfoundland and Labrador.

Competing interests: None declared.

\section{Address correspondence to:}

Dr Carla Dillon

School of Pharmacy, Rm H3447

Health Sciences Centre

300 Prince Philip Drive

St John's NL A1B 3V6

e-mail: cmdillon@mun.ca

Acknowledgements: We would like to thank the study participants. This research project is part of a larger program of Translational Research in Bariatric Care. It involves the collaboration of a team of researchers from Memorial University's Faculty of Medicine and School of Pharmacy. We would like to thank all members of the Newfoundland and Labrador Bariatric Care Translational Research Program team.

Funding: This research was supported in part through funding received from the Newfoundland and Labrador Centre for Applied Health Research, St John's, Newfoundland and Labrador. This project also received in-kind funding support from the Bariatric Surgery Program at Eastern Health, Newfoundland and Labrador. 